\title{
SPORTO PSICHOLOGIJOS IR EDUKOLOGIJOS PARADIGMA PASAULYJE IR LIETUVOJE
}

\author{
Kristina Motiejūnaite் ${ }^{1}$, Albertas Skurvydas ${ }^{2}$ \\ Valstybinè visuomenès sveikatos priežiüros tarnyba prie Sveikatos apsaugos ministerijos, Vilnius ${ }^{l}$, \\ Lietuvos kūno kultūros akademija, Kaunas'², Lietuva
}

\begin{abstract}
Kristina Motiejūnaitė. Sporto magistrè. Valstybinès visuomenès sveikatos priežiūros tarnybos prie Sveikatos apsaugos ministerijos Visuo-
\end{abstract} menès sveikatos strategijos skyriaus vyr. specialistė. Mokslinių tyrimų kryptis — sporto mokslo metodologija.

\section{SANTRAUKA}

Naujoji mokslo paradigma — naujas mokslinis raštingumas, nauja mokslo kultūra, kurios pagrindiniai bruožai — mastymo kritiškumas, abejonè, nuolatinè tiesos paieška ir nesibaigiantis dialogas su gamta, žmogumi, visuomene. Iki šiol vyraujant klasikinei mokslo paradigmai, sudètingos susireguliuojančios sistemos tiriamos atitrūkusiais nuo tikrovés ir neinformatyviais tyrimo büdais (Skurvydas, 2001).

Klasikinio mokslo atstovai ieško absoliučiai „tvirtu“ mokslinès tiesos apibrėžimo kriteriju (Kuhn, 1970; Carnap, 1996). Naujosios mokslo paradigmos šalininkai teigia, kad pagrindinis mokslo tikslas —artèti link didesnio realybès aiškumo supratimo, nes neįmanoma atskleisti universalios tiesos (Prigogine, 1997; Sagan, 1997; Kauffman, 2000).

Tyrimo tikslas - nustatyti, kokia moksliniu tyrimu paradigma vyrauja pasaulio ir Lietuvos sporto psichologijos ir edukologijos moksliniuose straipsniuose. Tikslui pasiekti buvo iškelti uždaviniai: išanalizuoti ir ìvertinti Lietuvos sporto psichologijos ir edukologijos moksliniu tyrimu paradigma, išanalizuoti ir ivvertinti pasaulio sporto psichologijos moksliniu tyrimu paradigma. Tyrimo objektas — sporto psichologijos ir edukologijos moksliniu tyrimu paradigma.

Atsitiktiniu būdu buvo pasirinkti ir išanalizuoti 102 socialiniu mokslu srities straipsniai, publikuoti Lietuvos ir užsienio moksliniuose žurnaluose: 29 sporto psichologijos krypties ir 73 edukologijos krypties publikacijos. Mokslo paradigma buvo nagrinejama, kaip mokslinès publikacijos atitinka šiuolaikinius pasaulinius reikalavimus. Jei publikacija neatitiko šiu reikalavimu, buvo priskiriama klasikinei mokslo paradigmai, jei atitiko — naujajai. Vertinimo kriterijai sudaryti remiantis moksliniams straipsniams keliamais reikalavimais, pateiktais $R$. A. Day knygoje „How to Write and Publish a Scientific Paper" (1979), J. R. Thomas ir J. K. Nelson knygoje „Research Methods in Physical Activity“ (1990), Lietuvoje publikuojamuose moksliniuose žurnaluose „Ugdymas. Kūno kultūra. Sportas “ir „, Sporto mokslas“.

Atlikta moksliniu straipsniu, publikuotu Lietuvos (,, Sporto mokslas“ ir „, Ugdymas. Küno kultūra. Sportas“) ir pasaulio (,, Journal of the Philosophy of Sport“, „, The Sport Psychologist“, „, Journal of Sport Sciences “, „, Scandinavian Journal of Medicine and Science in Sport“, „Journal of Sport and Exercise Psychology“) moksliniuose žurnaluose, analizè ir vertinimas remiantis šiuolaikiniais moksliniams straipsniams keliamais reikalavimais parodè, kad pasaulyje ir Lietuvoje vyrauja klasikine sporto psichologijos bei edukologijos mokslo paradigma.

Raktažodžiai: klasikine mokslo paradigma, naujoji mokslo paradigma, sporto psichologija, edukologija.

\section{IVADAS}

$\mathrm{P}$ aradigma (gr. paradeigma - pavyzdys, modelis) - mokslinès bendrijos priimtas mąstymo būdas, sąvokų tinklas, per kuri mokslininkas žvelgia į tikrovę (Kuhn, 1970). Paradigma nustato tuos rèmus, kurių ribose vykdomi tyrimai ir plètojamas mokslas.

Iki šiol vyraujant klasikinei mokslo paradigmai, sudetingos susireguliuojančios sistemos (SSS) tiriamos nuo tikrovès atitrūkusiais ir neinformatyviais būdais (Skurvydas, 2001). SSS yra sunkiai suprantama, nuo atsitiktinumu priklausanti, spontaniškai kintanti, nepakartojama, tiksliai neprognozuojama ir trapi tvarka, kuri turi būti tiriama nedeterminuotomis priemonèmis, leidžiančiomis suprasti jos kaitumą (Gleick, 1987; Bar-Yam, 1997; Prigogine, 1997; Holland, 1998; Kauffman, 2000).

Klasikinio mokslo atstovai ieško absoliučiai „tvirtų“ mokslinès tiesos apibrèžimo kriteriju (Kuhn, 1970; Carnap, 1996). Naujosios mokslo pa- 
radigmos šalininkai teigia, kad pagrindinis mokslo tikslas - artèti didesnio realybès aiškumo supratimo link, nes neimanoma atskleisti universalios tiesos (Prigogine, 1997; Sagan, 1997; Kauffman, 2000). Naujoji mokslo paradigma ragina didesni dèmesi kreipti į mokslinès tiesos ieškojimo principus, o ne i pasiektą rezultatą, nes niekados nesame tikri dèl galutinio rezultato patikimumo (Bak, 1996; Prigogine, 1997; Kauffman, 2000). Todèl metodologijos patikimumas tampa rimčiausiu mokslinès tiesos ieškojimo garantu (Skurvydas, 2001).

Skirtingos mokslo sritys gali būti tiriamos nevienodais metodais (Feyerabend, 1975; Schein, 1987). Edukologijos, psichologijos, sociologijos, antropologijos, sporto psichologijos ir nemažai kitų mokslo krypčių pirmenybę teikia tokiems tyrimo metodams, kurių klasikinè mokslo paradigma nevertina ir laiko nemoksliniais.

Remdamiesi šiais teiginiais iškèlème hipotezę, kad pasaulyje ir Lietuvoje vyrauja klasikinè sporto psichologijos ir edukologijos moksliniu tyrimu paradigma.

Lietuvos moksliniuose žurnaluose beveik nèra straipsnių, nagrinejjančių ir vertinančių sporto psichologijos ir edukologijos tyrimus bei ju svarbą. Publikacijos moksliniuose žurnaluose turètų geriausiai atskleisti mokslinių tyrimų paradigmą, todèl vertindami Lietuvos ir pasaulio moksliniuose žurnaluose publikuotus sporto psichologijos bei edukologijos mokslinius straipsnius siekème nustatyti šiuo metu vyraujančią sporto psichologijos ir edukologijos moksliniu tyrimų paradigmą.

Tyrimo tikslas - nustatyti, kokia moksliniu tyrimu paradigma vyrauja pasaulio ir Lietuvos sporto psichologijos ir edukologijos moksliniuose straipsniuose. Tikslui pasiekti buvo iškelti uždaviniai: išanalizuoti ir ivvertinti Lietuvos sporto psichologijos ir edukologijos mokslinių tyrimu paradigma, išanalizuoti ir ivvertinti pasaulio sporto psichologijos mokslinių tyrimų paradigmą.

Tyrimo objektas - sporto psichologijos ir edukologijos mokslinių tyrimų paradigma.

\section{TYRIMO METODAI}

Buvo taikomi šie tyrimo metodai: 1) literatūros šaltinių analizė; 2) straipsnių, publikuotu moksliniuose žurnaluose, analizé; 3) matematinè statistinè analizè.

Atlikta tiriamujų mokslinių straipsnių, publikuotų Lietuvos („Sporto mokslas“, „Ugdymas.
Kūno kultūra. Sportas“) ir pasaulio („Journal of the Philosophy of Sport“, „The Sport Psychologist", „Journal of Sport Sciences“, „Scandinavian Journal of Medicine and Science in Sport“, ,Journal of Sport and Exercise Psychology") moksliniuose žurnaluose, analizè ir vertinimas remiantis šiuolaikiniais moksliniams straipsniams keliamais reikalavimais.

Atsitiktiniu būdu buvo pasirinkti ir išanalizuoti 102 socialinių mokslų srities moksliniai straipsniai, publikuoti Lietuvos ir užsienio moksliniuose žurnaluose: 29 sporto psichologijos krypties ir 73 edukologijos krypties publikacijos. Mokslinès publikacijos buvo priskiriamos sporto psichologijos ir edukologijos krypčiai pagal tos mokslo krypties tyrimo objektus.

Išanalizuota ir îvertinta 13 Lietuvos moksliniuose žurnaluose „Ugdymas. Kūno kultūra. Sportas“ (1998-2002 m.) ir "Sporto mokslas“ (1996-2002 m.) publikuotuc sporto psichologijos krypties ir 73 edukologijos krypties moksliniu straipsnių, taip pat 16 sporto psichologijos krypties straipsnių, publikuotų užsienio moksliniuose žurnaluose: ,Journal of the Philosophy of Sport", „The Sport Psychologist", „Journal of Sport Sciences“ ir „Scandinavian Journal of Medicine and Science in Sport".

Mokslo paradigma buvo nustatoma analizuojant, kaip mokslinès publikacijos atitinka šiuolaikinius pasaulinius reikalavimus. Jei publikacija neatitiko šių reikalavimų, buvo priskiriama klasikinei mokslo paradigmai, jei atitiko - naujajai. Vertinimo kriterijai buvo sudaryti remiantis moksliniams straipsniams keliamais reikalavimais, pateiktais R. A. Day knygoje „How to Write and Publish a Scientific Paper“ (1979), J. R. Thomas ir J. K. Nelson knygoje „Research Methods in Physical Activity“ (1990), Lietuvoje publikuojamuose moksliniuose žurnaluose „Ugdymas. Kūno kultūra. Sportas“ ir „Sporto mokslas“.

Buvo sudaryta lentele iš keturiolikos pagrindinių kriterijų, atitinkančių naujosios mokslo paradigmos reikalavimus, keliamus mokslinèms publikacijoms. Jei publikacija atitiko šiuos reikalavimus, buvo priskiriama naujajai mokslo paradigmai, jei ne - klasikinei.

Mokslinėse publikacijose turèjo būti:

Lvade: 1) pateikta teorine ir praktinè tyrimo problema - pasaulinio lygio; 2) nusakytos tyrimo koordinatès (tyrimo aktualumas ir naujumas); 3) pateikti tyrimo tikslai; 4) apibrezžta reali ir aiški hipotezè. 
Metodikos skyriuje: 5) tyrimo metodika aprašyta taip, kad bet kuris tos srities specialistas galètu pakartoti tyrimą ir gauti tokius pačius ar panašius rezultatus.

Rezultatu skyriuje: 6) pateikti aiškūs ir logiški tyrimo rezultatai; 7) neapkraunant jais teksto; 8) neaptarinejjant rezultatų.

Rezultatu aptarimo ir išvadu skyriuje: 9) pateikta mokslinè hipotezé, nurodanti diskusiju krypti; 10) nurodytos diskusiju koordinatès, t. y. kokią teoriją ar dèsni papildo gauti tyrimo rezultatai; 11) gautų rezultatų palyginimas su kitu mokslininkų atliktais tyrimais; 12) diskusiju skyrius užbaigtas apibendrinimu; 13) pateiktos konkrečios išvados; 14) nedaugiažodžiaujama, o ieškoma bendru ryšių ir principų.

Visi kriterijai buvo surašyti tyrejo sudarytoje lenteleje. Kiekvieno kriterijaus atitiktis buvo vertinama pliusu, neatitiktis - minusu. Jei publikacija neatitiko kriterijaus, šalia buvo trumpai paaiškinta neatitikimo priežastis. Visos publikacijos buvo užkoduotos skaičiais nuo 1 iki 102. Statistinių ryšių stiprumas buvo vertinamas naudojantis susijusiu požymiu chi kvadrato $\left(\chi^{2}\right)$ kriterijumi. Kokybinių požymių statistinis ryšys tirtas susietų lentelių metodu. Remiantis lentelès duomenimis, buvo apskaičiuojamas chi kvadrato kriterijus ir jo laisvès laipsnių skaičius (df). Šie rodikliai leido nustatyti hipotezès, kad požymiai nèra susieti, tikimybę - p. Jei $p<0,05$, galèjome teigti, kad ryšys tarp požymių yra statistiškai patikimas. Naudoti statistinių išvadų patikimumo lygiai: $p>0,05$ - nepatikima (NS), $p<0,05-$ patikima.

\section{REZULTATAI}

Nagrinètu sporto psichologijos krypties straipsnių, publikuotų Lietuvos moksliniuose žurnaluose (SPLT), kurie atitiktų 12 šiuolaikinėms pasaulinėms mokslinèms publikacijoms keliamu reikalavimu, buvo du (15,4\%). 46,2\% SPLT atitiko aštuonis reikalavimus.

Užsienio moksliniuose žurnaluose publikuotu sporto psichologijos krypties straipsnių (SPUS), kurie atitiktų 14 mokslinèms publikacijoms keliamų reikalavimų, buvo $12,5 \%$. Šiuose žurnaluose tokiu publikacijų daugiausia atitiko dvylika — trylika kriteriju $(37,6 \%)$.

Edukologijos krypties straipsnių, publikuotuc Lietuvos moksliniuose žurnaluose (EKMS), kurie atitiktų visus naujosios mokslo paradigmos keliamus reikalavimus, buvo 1,4\%. Dažniausiai EKMS atitiko aštuonis kriterijus (12,7\%).

Moksliniu publikaciju ivvadas buvo analizuojamas remiantis keturiais kriterijais: pasaulinio lygio tyrimo problema, tyrimo koordinatès, tikslas, hipotezè. Visus šiuos kriterijus atitiko 30,8\% SPLT, 37,5\% SPUS ir 15,5\% EKMS (1 pav.).

Metodika pateikta taip, kad tyrimą galima būtų pakartoti, 92,3\% analizuotų SPLT, 81,3\% SPUS, $67,6 \%$ - EKMS ( 2 pav.).

Mokslinių publikacijų rezultatų skyrius buvo analizuojamas remiantis trimis kriterijais: tyrimu rezultatai turejjo būti pateikiami aiškiai ir logiškai, neapkraunant teksto ir nediskutuojant. Juos atitiko $15,4 \%$ SPLT, $43,8 \%$ SPUS ir 21,1\% EKMS.

Nè vieno mokslinių publikacijų rezultatų skyriui keliamo kriterijaus neatitiko $18,8 \%$ SPUS ir 32,4\% EKMS (3 pav.).

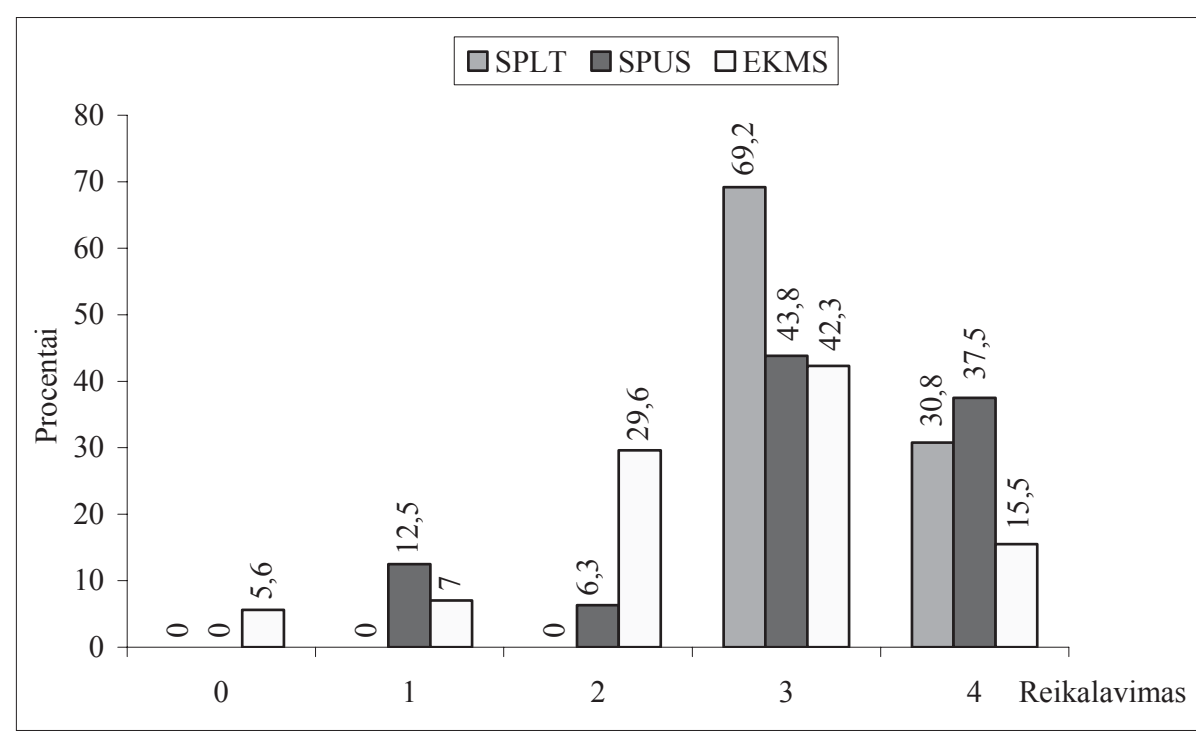

1 pav. Mokslinių straipsnių, publikuotuc Lietuvos ir pasaulio moksliniuose žurnaluose, skirstinys procentais pagal mokslo kryptị ir naujosios mokslo paradigmos keliamus reikalavimus įvadui 
2 pav. Mokslinių straipsnių, kuriuose metodika pateikta taip, kad tyrimą galima būtų pakartoti, procentinis skirstinys pagal mokslo krypti

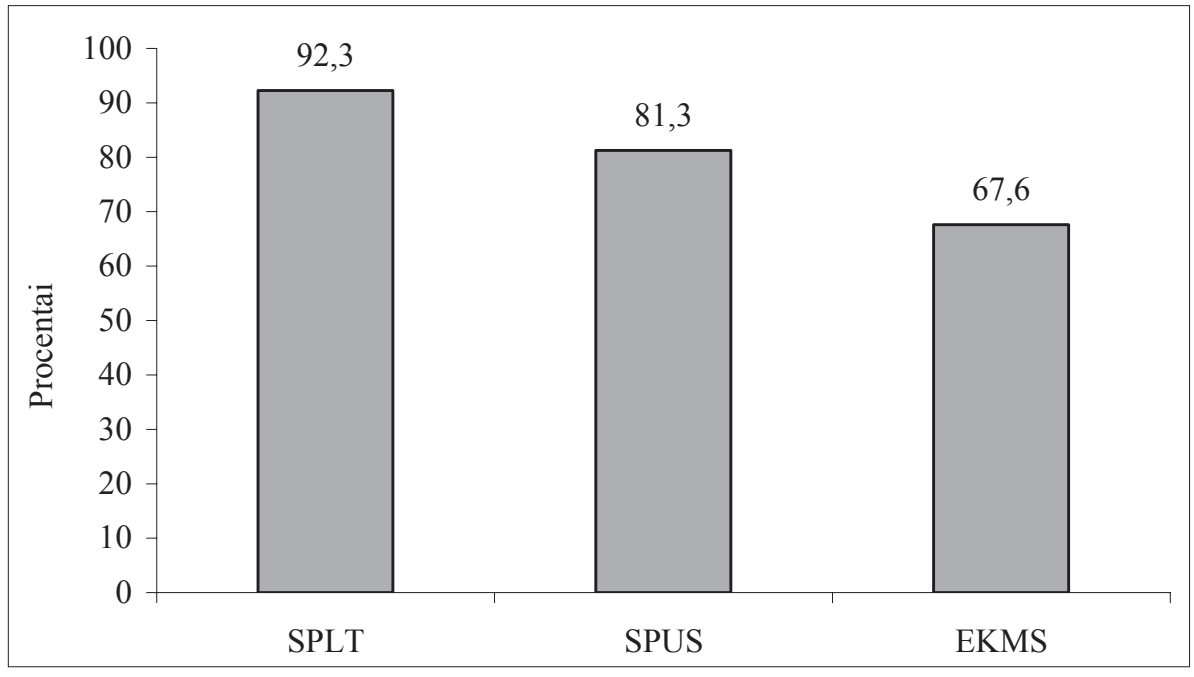

3 pav. Mokslinių straipsnių, publikuotų Lietuvos ir pasaulio moksliniuose žurnaluose, skirstinys procentais pagal mokslo kryptị ir naujosios mokslo paradigmos keliamus reikalavimus rezultatų skyriui

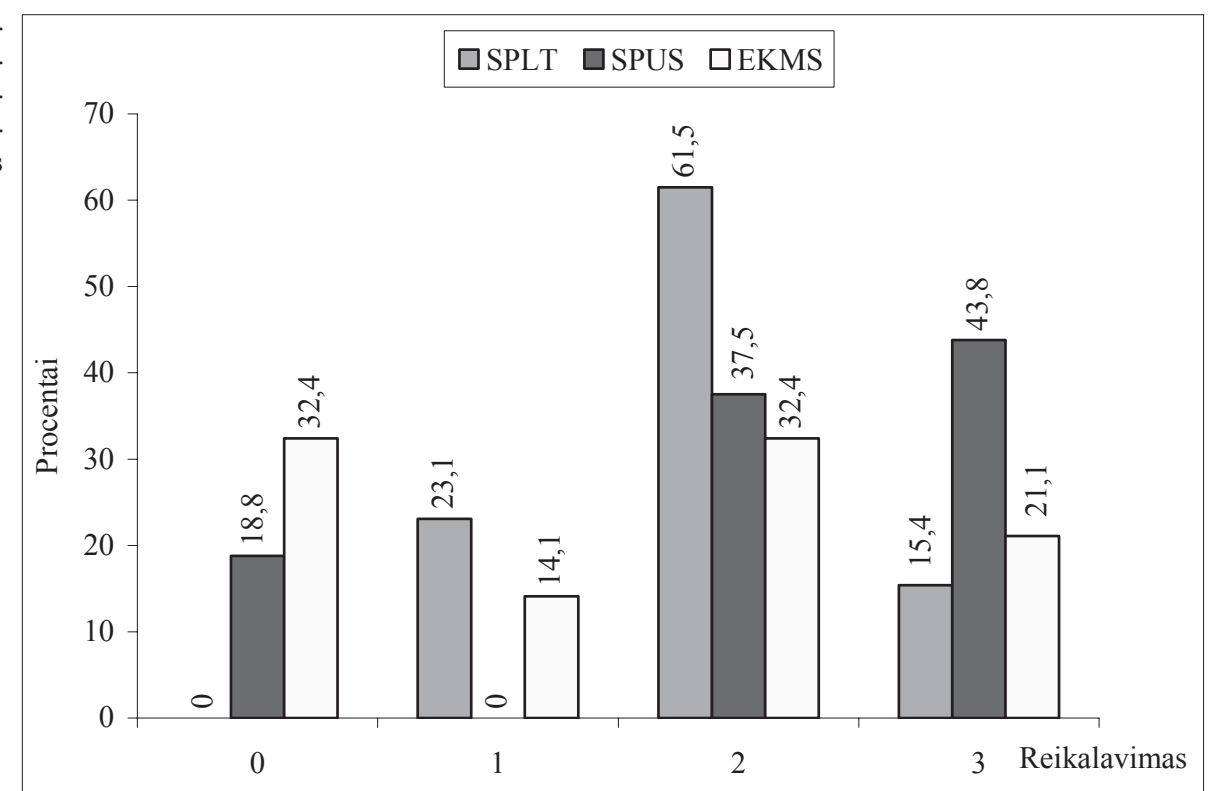

4 pav. Mokslinių straipsnių, publikuotų Lietuvos ir pasaulio moksliniuose žurnaluose, skirstinys procentais pagal mokslo krypti ir naujosios mokslo paradigmos keliamus reikalavimus rezultatų aptarimui ir išvadoms

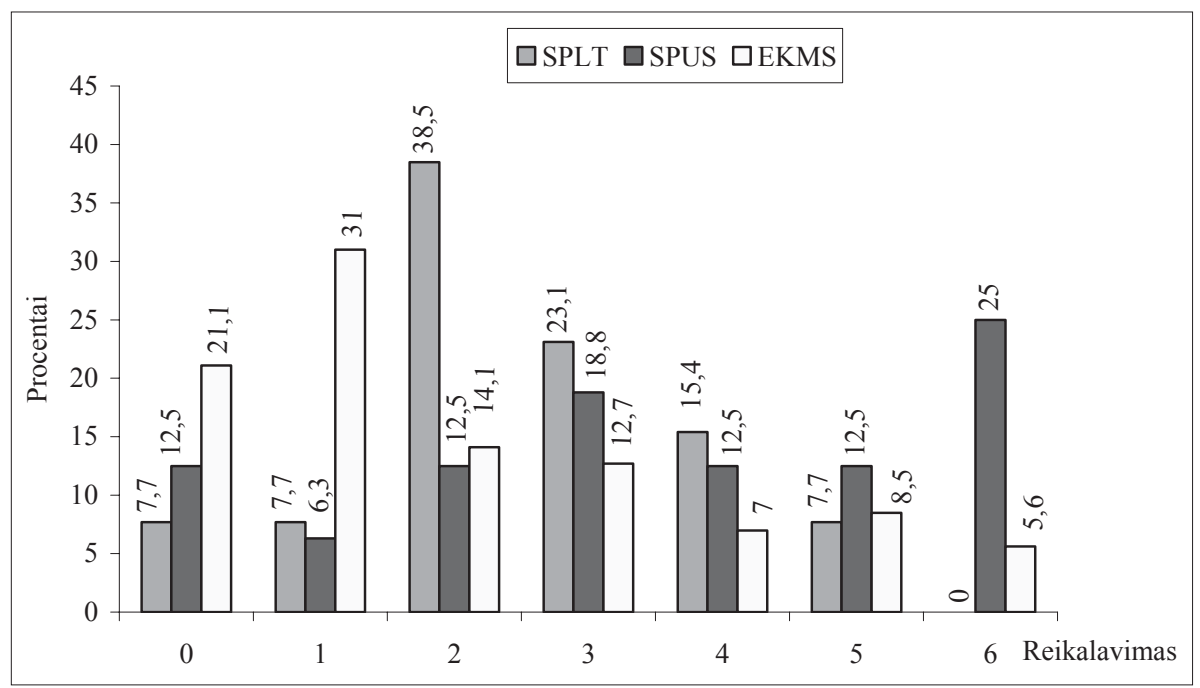

Mokslinių publikacijų rezultatų aptarimui ir išvadoms buvo keliami šie reikalavimai: pateikta mokslinė hipotezè, nurodanti diskusijų krypti, diskusiju koordinatès (turèjo būti aiškiai nurodoma, kokią teoriją ar dèsni papildo gauti tyrimo rezul- tatai), gautų tyrimo rezultatų palyginimas su kitų mokslininkų atliktaisiais, nesutapimo priežasčių analizè, glaustumas, bendrų ryšių, principuz paieška, diskusijų skyriaus apibendrinimas, konkrečios išvados (4 pav.). 


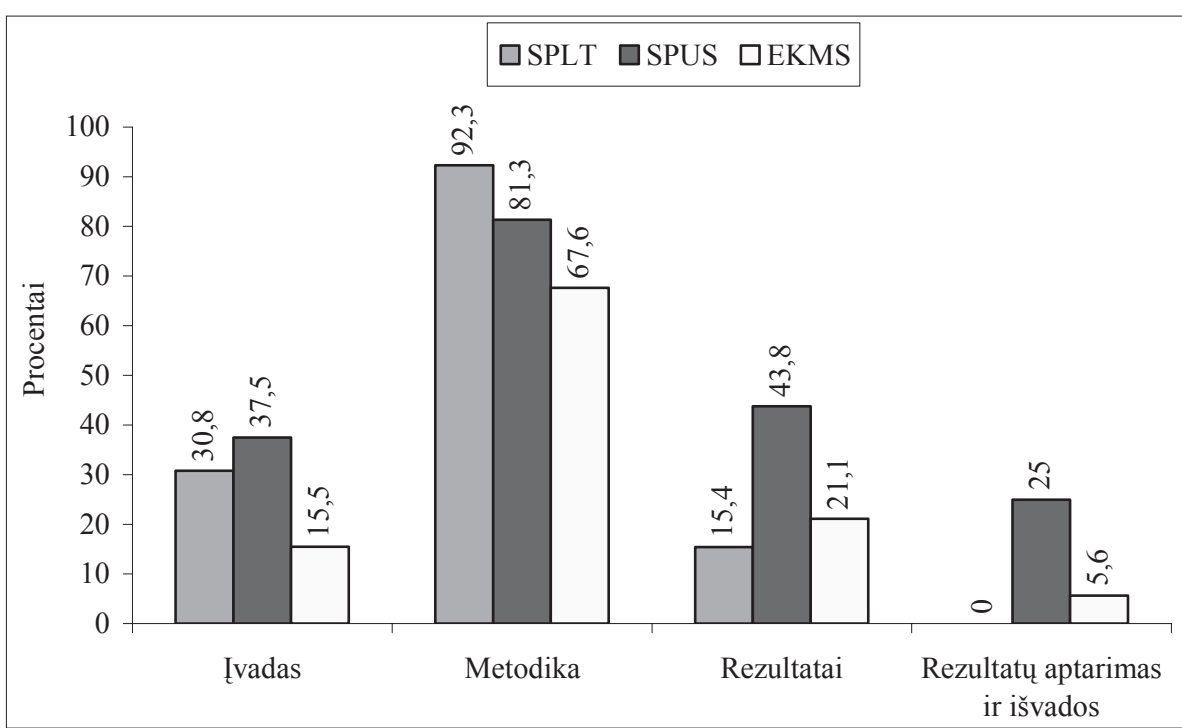

5 pav. Mokslinių straipsnių, publikuotų Lietuvos ir pasaulio moksliniuose žurnaluose, skirstinys procentais pagal mokslo kryptị ir naujosios mokslo paradigmos keliamus reikalavimus mokslinio straipsnio struktūrinėms dalims

Šiuos reikalavimus atitiko ketvirtadalis SPUS ir 5,6\% EKMS. Tokiu SPLT, kurie atitiktu visus naujosios mokslo paradigmos rezultatu aptarimui ir išvadoms keliamus reikalavimus, nebuvo.

Straipsnių, kurie neatitiktų nė vieno rezultatu aptarimui ir išvadoms keliamo reikalavimo, buvo ir Lietuvos, ir užsienio nagrinètuose moksliniuose žurnaluose. Dažniausiai SPLT rezultatų aptarimas ir išvados atitiko du reikalavimus $(38,5 \%)$, rečiausiai — šešis. Dažniausiai sporto psichologijos krypties mokslinių straipsnių, publikuotų ne Lietuvos moksliniuose žurnaluose, rezultatų aptarimas ir išvados atitiko šešis reikalavimus (25\%), rečiausiai - vieną (6,3\%). EKMS rezultatu aptarimas ir išvados dažniausiai atitiko vieną reikalavimą (31\%), rečiausiai - šešis $(5,6 \%)$.

\section{REZULTATUQ APTARIMAS}

Tyrimo hipotezè pasitvirtino - pasaulyje ir Lietuvoje vyrauja klasikiné sporto psichologijos ir edukologijos mokslinių tyrimų paradigma. Lietuvos moksliniuose žurnaluose publikuotų sporto psichologijos krypties moksliniu straipsnių, kurie atitiktų visus naujosios mokslo paradigmos keliamus reikalavimus, nebuvo. Užsienio moksliniuose žurnaluose publikuotu sporto psichologijos krypties straipsnių, atitinkančių visus kriterijus, buvo $12,5 \%$. Lietuvos moksliniuose žurnaluose publikuotu edukologijos krypties straipsniu, atitinkančių visus naujosios mokslo paradigmos keliamus reikalavimus, buvo 1,4\%. Dažniausiai nagrinètuose Lietuvos moksliniuose žurnaluose publikacijos atitiko aštuonis kriterijus.

Lietuvos moksliniuose žurnaluose publikuotu sporto psichologijos krypties straipsnių, kurie atitiktų dvylika mokslinėms publikacijos keliamų reikalavimų, buvo du (15,4\%). Užsienio mokslinių žurnalų sporto psichologijos krypties ketvirtadalis visu publikacijų atitiko dvylika reikalavimų, tačiau buvo ir tokių, kurios atitiko tik du ar tris kriterijus (po 6,3\%). Be to, analizuodami užsienio mokslinių žurnalų publikacijas pastebejome, kad straipsniai, publikuoti žurnaluose su citavimo indeksu, dažniau atitiko mokslinėms publikacijoms keliamus reikalavimus nei tie, kurie publikuoti žurnaluose be citavimo indekso.

Darome prielaidą, kad nemaža dalis Lietuvos ir pasaulio mokslininkų dar nèra pakankamai susipažinę su mokslinių straipsnių rengimo technologija. Būtent - su tyrimui ir jo aprašymui keliamais reikalavimais: problemos identifikacija ir apibrèžimas; kruopštus ir efektyvus su tyrimo problema susijusios literatūros šaltinių tyrinejjimas ir aprašymas; tiksliai nusakyta ir apibrèžta tyrimo hipotezė; aiškiai apibūdintas tyrimo objektas; rezultatų analizavimas ir aprašymas bei gautu duomenų reikšmingumo ir išvadų aptarimas.

Pasak A. Day (1979), viena svarbiausių mokslinio straipsnio dalių yra ịvadas. Jame turi būti aiškiai nusakyta tyrimo problema, pasirinkta tinkama literatūra, tyrimo metodai ir pateikti svarbiausi tyrimo rezultatai. Be to, ivvadas turètų būti parašytas taip, kad tyrimo problemą suprastų ir kitu sričių specialistai, todèl nereikètu stengtis priblokšti skaitytoją per daug technine kalba.

Apžvelgę tyrimo rezultatus nustatème, kad daugiau nei pusẻ išanalizuotų mokslinių straipsnių i̇vadų neatitiko visų i̇vadui keliamų reikalavimų. Dažniausiai analizuotų mokslinių publikacijų Ł̇vadas neatitiko hipotezei keliamų reikalavimų, t. y. hipotezė nebuvo aiški ir reali. Anot K. Popper 
(2001), visa mokslinè veikla yra hipotezių kūrimas ir tikrinimas. Tačiau tik penktadalis edukologijos krypties ir šiek tiek daugiau nei pusè sporto psichologijos krypties mokslinių publikaciju atitiko ši reikalavimą. Trečdalio Lietuvos moksliniuose žurnaluose publikuotų straipsnių tyrimo problema buvo ne pasaulinio lygio, tyrimo aktualumas ir naujumas buvo pateiktas $75 \%$ SPUS, bei $69 \%$ EKMS. Kadangi nèra ir negali būti „lietuviško mokslo", tai ir tyrimo problema turi būti apžvelgiama platesniu mastu.

Užsienio publikacijų ivadai atitiko ne mažiau nei tris iš keturių ivadui keliamų reikalavimų, tuo tarpu net trečdalis Lietuvoje publikuotų straipsnių ỉvadų atitiko du ir mažiau reikalavimų. Todèl manome, kad nemaža dalis Lietuvos mokslininkų per mažai skiria dèmesio įvado rašymui: tyrimo problemos analizavimui, koordinačiu ìvardijimui ir hipotezès formulavimui.

Ivade turi būti pateikiami tyrimo metodai, jei yra būtinybè - ir konkrečių metodų pasirinkimo priežastys. Metodikos skyriuje visa tai aprašoma labai išsamiai. Pagrindinis metodikos skyriaus tikslas yra aprašyti tyrimo metodus taip, kad bet kuris tos srities specialistas galetu pakartoti tyrimą ir gautu panašius rezultatus (Thomas, Nelson, 1990). Pasak A. Day (1979), recenzentas rekomenduotų atmesti rankrašti, nepaisydamas rezultatų ispūdingumo, jei atidžiai perskaitęs metodikos skyrių suabejotų, ar pavyktų pakartoti tyrimą.

$32,4 \%$ EKMS metodikos skyriai nebuvo pakankamai išsamūs. Manome, kad edukologijos krypties mokslinèse publikacijose trūksta analizès tikslumo, t. y. net trečdalio juose pateiktu tyrimu nebūtų galima pakartoti.

Mokslinès publikacijos rezultatų skyrius yra pats svarbiausias ir reikšmingiausias. Jame trumpai apžvelgiamas visas tyrimas nekartojant to, kas jau buvo minèta metodikos skyriuje, bei aprašomi gauti duomenys. Be to, tyrimo rezultatai pateikiami aiškiai ir logiškai, neapkraunant jais teksto ir nediskutuojant (Thomas, Nelson, 1990; Cohen et al., 2000). Visus šiuos reikalavimus atitiko 43,8\% išnagrinètų SPUS ir tik 15,4\% SPLT. Penktadalis
EKMS atitiko visus tris keliamus reikalavimus, daugiau nei trečdalis EKMS neatitiko nė vieno. Pagrindinè problema yra ta, kad nemažai mokslininkų, rašydami mokslinius straipsnius, tyrimo rezultatus ir jų aptarimą pateikia kartu, nors šiuose skyriuose aprašomi skirtingi dalykai. Rezultatu skyriuje turètų būti pateikta, kas yra atrasta, o rezultatu aptarimo - tyrimo duomenų interpretacija, todèl jų sujungti nevertètu.

Rezultatų aptarimo arba diskusiju skyriuje apibendrinami rezultatai, parodomas ryšys su anksčiau publikuotais tyrimais, nagrinejjama teorinè bei praktinè tyrimo reikšme ir pateikiamos išvados. Tokie reikalavimai buvo keliami ir nagrinètoms sporto psichologijos bei edukologijos mokslinėms publikacijoms. Ne mažiau kaip penkis iš šešių reikalavimų, keliamų mokslinès publikacijos diskusijų skyriui, atitiko $37,5 \%$. SPUS, $14,1 \%$ EKMS ir tik 7,7\% SPLT. Tai rodo, kad gerai parašyti diskusijų skyrių yra labai sudètinga (Day, 1979; Thomas, Nelson, 1990).

Anot A. Day (1979), daugelis diskusijų skyrių yra per ilgi ir juose daugiažodžiaujama. Tai patvirtina ir šis tyrimas, nes tik $15,4 \%$ SPLT ir $28,2 \%$ EKMS diskusiju skyriuose to nedaroma. $\breve{S}$ i reikalavimą atitiko ir mažiau nei puse nagrinètu užsienio mokslinių žurnalų publikacijų. Tik penktadalyje Lietuvoje publikuotų straipsniu diskusijų skyriuose buvo pateiktos mokslinès hipotezès, nurodančios diskusijų kryptis, ketvirtadalyje šių straipsnių — diskusijų koordinatès. Beveik 40\% Lietuvos mokslinių žurnalu publikacijų išvados nèra konkrečios ir neatitinka tyrimo rezultatų.

\section{IŠVADOS}

1. Pasaulyje, kaip ir Lietuvoje, vyrauja klasikinè mokslo paradigma, kurios pagrindiniai bruožai - pastovumo, stabilumo, nekintamumo, apibrèžtumo, universalių metodų ir dèsnių paieška.

2. Pasaulyje ir Lietuvoje nepakanka intelektinių galiu, kompetencijos matyti nagrinejjamą problemą mokslinių tyrimų kontekste.

\section{LITERATŪRA}

Bak, P. (1996). How Nature Works: The Science of Self Organized Criticality. New York: Springer-Verlag.

Bar-Yam, Y. (1997). Dynamics of Complex Systems. Massachusetts: Perseus Books.

Carnap, R. (1996). Philosophical Foundations of Physics. New York, London.
Cohen, L., Manion, L., Morrison, K. (2000). Research Methods in Education. London, New York.

Day, R. A. (1979). How to write and Publish a Scientific Paper. Philadelphia.

Feyerabend, P. (1975). Against Method. London: New Left Books. 
Gleick, J. (1987). Chaos: Making a New Science. New York: Viking.

Holland, J. H. (1998). Emergence: From Chaos to Order. Cambridge, Massachusetts: Perseus Books.

Kauffman, S. A. (2000). Investigations. New York: Oxford university Press.

Kuhn, T. (1970). The Logic of Scientific Revoliutions. Chicago.

Popper, K. R. (2001). Rinktinè. Vilnius: Pradai.
Prigogine, I. (1997). The End of Certainity. Time, Chaos, and New Laws of Nature. New York: The Free Press.

Sagan, C. (1997). The Demon-Haunted: Science as a Candle in the Dark. London: Headline Book Publishing.

Schein, E. H. (1987). The Clinical Perspective in Fieldwork. Newbury Park, CA: Sage.

Skurvydas, A. (2001). Naujoji mokslo paradigma. Sporto mokslas, 4 (26), 2-6.

Thomas, J. R., Nelson, J. K. (1990). Research Methods in Physical Activity. USA: Versa Press.

\title{
THE PARADIGM OF SPORT PSYCHOLOGY AND EDUCATIONAL SCIENCE RESEARCH IN THE WORLD AND IN LITHUANIA
}

\author{
Kristina Motiejūnaité ${ }^{1}$, Albertas Skurvydas ${ }^{2}$ \\ State Public Health Service under the Ministry of Health, Vilnius ${ }^{1}$, \\ Lithuanian Academy of Physical Education, Kaunas ${ }^{2}$, Lithuania
}

\begin{abstract}
The new science paradigm is built on new scientific literacy and new science culture. Critical thinking, doubt, ongoing search for the truth, endless dialogue with nature, person and society are the main elements of it. Currently the traditional science paradigm is dominating and sophisticated self-organization systems are researched by unreal, uninformative research techniques (Skurvydas, 2001).

The exponent of the traditional science is searching absolutely "strong" criteria of science truth (Carnap, 1996; Kuhn, 1970). The exponents of the new science maintain that the main purpose of science is to approach towards the better understanding of the reality definition, because there is not possibly to discover the universal truth (Prigogine, 1997; Sagan, 1997; Kauffman, 2000).

The purpose of the research is to identify predominating science research paradigms in the world and Lithuanian sport psychology and educational science magazines. The main goals are: to explore and to evaluate the paradigm of Lithuanian sport psychology and educational science research. The subject of the study is the paradigm of sport psychology and educational science research.

102 studies of social science published in world and Lithuanian magazines were chosen randomly for this research -29 sport psychology publications and 73 publications of the education area.

Science research paradigm was identified on the ground of equivalence to the contemporary worldwide requirements for scientific publications. If the publication did not meet those requirements it was classified as traditional paradigm, if the publication met those requirements it was classified as new paradigm. Criteria for evaluation were created according to the requirements for scientific studies which were given in the works of R. A. Day ("How to write and publish a scientific paper", 1979) and J. R. Thomas \& J. K. Nelson ("Research methods in physical activity", 1990) and to the requirements for publications which were placed in Lithuanian science journals "Education. Physical training. Sport" and "Science of sport".

Analysis and evaluation of publications in Lithuanian ("Education. Physical training. Sport" and "Science of sport") and world ("Journal of the Philosophy of Sport", "The Sport Psychologist", "Journal of Sport Sciences”, „Scandinavian Journal of Medicine and Science in Sport“, „Journal of Sport and Exercise Psychology") science magazines have shown that traditional science research paradigm of sport psychology and educational science predominates in the world and Lithuanian research.
\end{abstract} science.

Keywords: traditional science paradigm, new science paradigm, sport psychology, educational

Gauta 2006 m. gegužès 24 d.

Received on May 24, 2006

Priimta 2006 m. gruodžio $6 \mathrm{~d}$.

Accepted on December 6, 2006
Kristina Motiejūnaitė

Valstybinė visuomenès sveikatos priežiūros tarnyba prie Sveikatos apsaugos ministerijos

(State Public Health Service under the Ministry of Health)

Kalvariju g. 153, LT-08221 Vilnius

Lietuva (Lithuania)

Tel +370 59850916

E-mail kmotiejunaite@yahoo.com 